\title{
Lanreotide Acetate Copolymer Microparticles
}

National Cancer Institute

\section{Source}

National Cancer Institute. Lanreotide Acetate Copolymer Microparticles. NCI Thesaurus.

Code C53437.

A prolonged-release depot suspension of microparticles containing the acetate salt of lanreotide, a synthetic peptide analog of the naturally occurring somatostatin, and copolymers. Lanreotide inhibits the secretion of growth hormone $(\mathrm{GH})$ by binding to pituitary somatostatin receptors, and may inhibit various other hormones, including thyroid-stimulating hormone (TSH) and the gastroenteropancreatic hormones insulin, glucagon and gastrin. This agent has a much longer duration of action than natural somatostatin and is selective towards the inhibition of growth hormone. 